\title{
The Articulation of a Telephone Circuit.
}

THE best method of testing telephone circuits and apparatus is a problem to which a great deal of attention has been devoted of recent years. Speech is carried over a telephone circuit by means of certain frequency components produced by the voice of the speaker at the sending end and received by the listener at the receiving end. If the components arriving at the listener's ear are exactly the same as when they left the speaker's mouth, the circuit would have a hundred per cent efficiency. There are two principal reasons, however, why the components arriving at the listener's ear are not the same as those leaving the speaker's mouth. In passing along the circuit the amplitude of the waves is attenuated ; they thus become weaker. The amount of the attenuation also varies with the frequency, and hence the waves become distorted. Again, components which were not originally present are produced in the circuit. These are due either to noise or to the overloading of some part of the circuit. Their effect is to raise the threshold values at which the ear can hear different notes. In Electrical Communication for January, J. Collard gives a method by means of which the effect of given noises on the 'articulation' of a telephone circuit can be computed much more quickly than by the ordinary methods.

In the usual method of testing, a series of syllables chosen at random are spoken into the telephone, the listener writing down what he imagines he hears. The ratio of the number of syllables correctly received to the total number of syllables sent gives an indication of the quality of the circuit. Unfortunately, the value thus obtained depends not only on attenuation and distortion, which are produced by the circuit, but also on faulty pronunciation by the speaker and faulty hearing by the listener. The value, therefore, varies with the speakers and the listeners; a great number of tests have to be taken before we can tell what is the approximate mean value.

The author gives empirical formulæ by means of which the ideal sound articulation can be approximately computed. It is not affected by careless pronunciation by the speaker or inattentive hearing by the listener. Once a circuit has been set up, articulation tests can be made on it and the value of the articulation obtained, but there are many cases in which it is desired to know before installing a given circuit or before inserting a given piece of apparatus in the circuit what the articulation will be, and this can be found in a few minutes by the author's method.

It has been calculated that to obtain a value of the articulation with a probable error of one per cent, it is necessary to speak 5000 syllables into the circuit. If there are ten pieces of apparatus to be tested, this would mean that 50,000 syllables would have to be called. The usual rate of calling is 20 per minute. Taking into account also the time required for calibrating the experimenters, the total time will be about 50 hours. The saving effected, therefore, by using the new empirical formulæ is a substantial one. In a previous paper published in Electrical Communication for January of last year, the author showed that articulation has much the same value whether English, French, Cerman, or Italian be used. It appears, therefore, that his method is applicable to other languages with little, if any, modification.

\section{Whaling and Fishing in the North Atlantic. ${ }^{1}$}

IN the autumn of 1923 the Norwegian Government appointed a whaling committee, under the chairmanship of Dr Johan Hjort, to carry out a scientific study of whaling and of the various factors in the sea which govern the life and migrations of whales. This committee at once approached the British Discovery Committee with a proposal that the two bodies should co-operate in this work. As a result of the negotiations which followed, it was agreed that, at any rate to begin with, the best arrangement would be for the Discovery to operate on the Antarctic whaling grounds, especially those worked from the Falkland Islands Dependencies, while the Norwegian investigators concentrated upon work in the North Atlantic.

In accordance with this agreement, a number of investigations have been carried out in northern seas during the years 1924-1928 under the administrative direction of the Norwegian whaling committee, the results of which have now been published in a very full report of some 550 pages. This report, although entitled "Whales and Plankton in the North Atlantic", deals not only with the occurrence and distribution of whales and their food but also with the occurrence and habits of the various species of fish of economic importance.

The two great sea areas lying west of Greenland (Davis Strait) and to the eastward of it (Norwegian Sea) have been studied in detail. Reference is made at the outset to two cruises made by Jensen during the summers of 1908 and 1909 in the brig Tjalfe, when that indefatigable investigator prospected for fish along the entire western seaboard of Greenland,

1 Whales and Plankton in the North Atlantic (a contribution to the 1 Whales and Plankton in the North Atlantic (a contribution to the
work of the Whaling Committee and of the North-Eastern Area Comwork of the Whaling Committee and of the North-Eastern Area Committee), Conseil Permanent International pour l'Fxploration de la 551. (Copenhague: Andr. Fred. Hgst et Fils, 1929.) $21 \cdot 50 \mathrm{Kr}$. including fjords, inshore waters, banks, and deep sea - a vast tract extending from $60^{\circ} \mathrm{N}$. to $71^{\circ} \mathrm{N}$. Along this enormous distance the distribution and biology of all the more important edible fishes were investigated, and the fact established that the very limited fishery of this region is due not to the absence of marketable fish but to the primitive equipment of its fishermen and their difficulty in disposing of their catch. There is an abundance of good fish, including common cod, fjord cod, halibut, Greenland or black halibut, the long rough dab, and two species of catfish.

During the years 1924-28 fishing expeditions to Davis Strait, financed by Messrs. I. O. and O. S. Hellyer of Hull and led by Mr. Engvald Baldersheim of Bergen, have proved extraordinarily successful, and form striking examples of what can be done to solve the difficult problems of organisation involved in fishing in very distant seas. To this region Hjort proceeded in the research vessel Michael Sars in 1924 and there carried out exhaustive fishing and hydrographical investigations.

The course of modern whaling is traced from the time of its initiation by Svend Foyn in Finland about the year 1870 until the present day, when its operations extend to almost all the waters of the globe. In a section written by Andr. Ingebrigtsen, himself a practical whaler of more than thirty years' experience, it is shown that with few exceptions the commercial pursuit of the whale sooner or later reduced the stock so greatly that whaling had to be abandoned either temporarily or permanently as unremunerative. Convincing details of the growth and decline of many whale fisheries are given. From about the year 1880 onwards, a number of whaling stations were established along the coast of Finmark and the number of boats rapidly increased from four in 1880 
to thirty-four in 1885 . The fatal result of this increase in the intensity of the fishery was soon apparent, for after about the year 1900 whaling at most of the Finmark stations ceased to pay and steadily declined. In 1905 most of the companies transferred their headquarters to Bear Island and Spitsbergen, but there too the industry was not of long duration. Too many boats destroyed the fishery, and by 1910 fishing in these waters was entirely abandoned. Subsequent attempts to revive the industry at Spitsbergen in 1920 and 1925-26 proved ruinous to the companies concerned.

Whale fishing off Iceland commenced about the year 1890 with eight whaling vessels. The catch at first was good and the number of boats increased to thirty in 1902. Thereafter there followed a steady decline in the catches. One station after another had to close, and Iceland whaling ceased altogether in 1915. The history of the whale fishing at the Faroes is in many ways similar to that of Finmark and Iceland. As the number of boats increased the catch per boat greatly decreased, and many stations ceased to operate. But during the War whaling stopped to a large extent. This proved good for the stock, and post-War catches off the Faroes, with fewer boats as compared with the number employed before the War, have yielded reasonable profits.

The same tale of rapid initial growth and subsequent decline is told of whaling in the Straits of Gibraltar, off South Africa, and on the west coast of America, and in a final sentence Ingebrigtsen states his firm conviction that the great modern extension of whaling in the Antarctic will undoubtedly, in spite of its vast tracts of ocean and apparently enormous numbers of whales, produce in the course of some years the same results as in all other watersnamely, a decreasing stock of whales from year to year.

G. A. S.

\section{University and Educational Intelligence.}

Cambridge.-At King's College the following have been elected to Fellowships: Mr. A. E. Ingham, reader in mathematics at the University of Leeds; and Mr. R. F. Kahn, Wrenbury Scholar (1928) and Adam Smith prizeman (1929).

CARDIFF,-H.R.H. the Prince of Wales will visit Cardiff on May 21 to open the now chemistry and physics wing of the University College, and the Department of Public Health of the Welsh National School of Medicine.

Mr. H. J. Phelps has been appointed as assistant lecturer and demonstrator in physiology.

EDINBURGH.-.-On the recommendation of the Faculty of Medicine, the Cameron Prize for 1930 has been awarded to Dr. George R. Minot, physician-inchief, Collis P. Huntingdon Memorial Hospital of Harvard, Boston, Mass., and Dr. William P. Murphy, assistant physician, Peter Bent Brigham Hospital, Boston, Mass., conjointly, for their work on the liver treatment of pernicious anæmia.

The Senatus has resolved to offer the honorary degree of doctor of laws to the following, among others : Sir Thomas Barlow, Physician-Extraordinary to H.M. the King ; Sir Otto Beit, trustee of the Rhodes Trust and founder of the Beit Memorial Fellowships for Medical Research; Sir William Hardy, director of food investigation, Defartment of Scientific and Industrial Research; Sir David Wallace, consulting surgeon to the Royal Infirmary, Edinburgh; Prof. W. W. Watts, professor of geology, Imperial College of Science, South Kensington; Prof. K. F. Wenckebach, emeritus professor of medicine, University of Vienna.

\section{Historic Natural Events.}

Mar. 23, I233. Thunderstorm and Floods.-There was a great and terrible tempest of thunder, and after followed a marvellous wet summer with many floods.

Mar. 23, 1913. Electrical Storm.-An usually severe electrical storm occurred in the western part of Kansas, U.S.A. High winds were blowing from south-west or west, and the air was warm, very dry, and filled with dust; there was no rain. Windmills, especially steel mills mounted on wooden supports, became so highly charged with static electricity that anyone touching them received a distinct, sometimes a severe shock. At Tribune, sparks two or three inches long were drawn from a wire running to a windmill. Telephone and telegraph wires and wire fences also became charged, and in Scott County, where the disturbance was most severe, a prairie fire is thought to have been started by sparks at a break in a wire fence, as in several places distinct sparks were noted on holding the broken ends of wire fences together. In Thomas County all green vegetation was killed, and in Sheridan County the wheat turned brown. The sky was obscured by a leaden or copper-coloured haze, and most people experienced nervous depression.

Mar. 24, r878. Eurydice Squall.-A. V-shaped trough of low pressure crossed England from northwest to south-east, and with its passage the wind changed from a moderate westerly breeze to a northwesterly gale. The wind velocity was not especially great, but there were some violent north-westerly squalls with sleet or snow, during one of which the training ship H.M.S. Eurydice foundered with all hands off Dunnose Head, near Ventnor. The loss of life was about 300 .

Mar. 24, I895. Gale.-This was described as the worst gale of the nineteenth century in the English Midlands. At 8 A.M., a well-marked depression was centred over the Shetland Isles, and during the afternoon a small but intense secondary depression traversed England and Wales with a velocity of 58 miles per hour. The greatest destruction was caused by a south-westerly gale along a narrow belt (only $30-50$ miles in width) to the right or south-east of the track followed by the centre of the secondary. Very great damage was done to property, many churches were injured and thousands of trees uprooted, and several lives were lost. In the observatory at Birmingham the oscillation of the building stopped the elock.

Mar. 25, I24 I. Drought.-It is recorded in Matthew Paris's Chronicle that "From the Annuciation to SS. Simon and Jude (Mar. 25-Oct. 28), continued drought and intolerable heat dried up deep lakes and extensive marshes, drained many rivers, parched up the warrens, and suspended the working of mills; hence the pastures withered away, herbage died, and consequently the flocks and herds pined away with hunger and died".

Mar. 26, I8r2. Earthquake in Venezuela.-The town of Caracas was utterly ruined by an earthquake felt throughout Venezuela and as far as Carthagena (600 miles). The shock occurred shortly after 4 P.M. As it was Ascension Day, large crowds had collected in the churches before the processions through the streets began, and three or four thousand persons were killed by the fall of the roofs. Throughout Venezuela, more than 20,000 persons perished. On April 24, the first eruption of the Soufriere of St. Vincent since 1718 began. The noise from it was heard at Caracas (nearly 400 miles).

Mar. 27, 1606. Great Storm in Belgium.-At 8 A.M. began a great tempest of wind which continued

No. 3151, VoL. 125] 